\title{
Apologetika Presuposisi Triperspektivalisme Cornelius Van Til Terhadap Agnostisisme
}

\author{
Kalis Stevanus \\ Sekolah Tinggi Teologi Tawangmangu \\ kalisstevanus91@gmail.com \\ Ivo Arbie Mauclau \\ Sekolah Tinggi Teologi Tawangmangu \\ godsarrowclothing@gmail.com
}

\begin{abstract}
Widespread agnostic thinking poses a severe threat to religious communities, including the Christian faith. This discussion uses a descriptive qualitative method with a literature study approach aimed at presenting an apologetic model of agnosticism, which still doubts the existence of God the Creator. This thought contradicts the Christian faith, which states that God exists and is actively involved in the continuity of His creation and has physically manifested His existence by incarnating as a human in the person of Jesus Christ. Based on the facts internally in the Bible and externally outside the Bible, the points in the world can be used for apologetics to show that Christian theism is rationally true. It is concluded that Christians need to implement the presuppositional apologetics model proposed by Van Til in dealing with agnostics. His apologetic method is based on the presupposition of the truth of God's Word by starting with God. Thus, according to Van Til, the goal of apologetics is nothing but bringing people to God.
\end{abstract}

Keywords: Apologetics, Agnosticism, Cornelius Van Til

\begin{abstract}
Abstrak
Di tengah merebaknya pemikiran agnostik menimbulkan ancaman serius bagi umat beragama termasuk iman Kristen. Pembahasan ini menggunakan metode kualitatif deskriptif dengan pendekatan studi kepustakaan bertujuan untuk menyajikan model berapologi terhadap Agnostisisme yang masih menyangsikan eksistensi Tuhan sang Pencipta. Hal ini bertolak belakang dengan iman Kristen yang menyatakan bahwa Tuhan itu ada dan terlibat aktif dalam keberlangsungan ciptaan-Nya, serta telah menyatakan eksistensi-Nya secara lahiriah dengan berinkarnasi menjadi manusia dalam pribadi Yesus Kristus. Berdasarkan fakta-fakta secara internal di dalam Alkitab maupun eksternal di luar Alkitab, yakni faktafakta di dunia dapat dipakai untuk berapologi menunjukkan bahwa teisme Kristen benar adanya secara rasional. Diperoleh kesimpulan bahwa orang Kristen perlu mengimplementasikan model apologetika presuposisional yang dicetuskan Van Til dalam menghadapi kaum agnostik. Metode apologetikannya berpijak pada presuposisi kebenaran Firman Tuhan dengan memulai dengan Tuhan. Dengan demikian, tujuan berapologi menurut Van Til tidak lain adalah membawa orang kepada Tuhan.
\end{abstract}

Kata-kata kunci: Apologetika, Agnostisisme, Cornelius Van Til 


\section{PENDAHULUAN}

Pada prinsipnya agama tidak dapat dilepaskan dengan konsep Tuhan sebagai pusat ritus pada keagamaan. Konsep Tuhan lahir dari suatu pertanyaan akan fenomena semesta alam yang mendasari pijakan cara berpikir masyarakat pada umumnya, sesuatu yang sulit dipahami, dijelaskan, tetapi kehadiran-Nya tampak dalam ciptaan yang maha besar. Hal inilah yang mendorong untuk manusia terus menjelaskan keberadaan kekuatan yang mengendalikan alam semesta ini dalam hal ini Tuhan. Pada perkembangan dewasa modern saat ini salah satu paham yakni, agnostisisme menjadi tumpuan perspektif bagi dewasa modern saat ini dalam menyikapi tingkat reliougitas mereka. Keraguan melalui praduga-praduga yang terus berkembang, menuntut mereka untuk melihat kehidupan dengan tidak berfokus pada kata Tuhan. Para ilmuwan, kaum terpelajar, akan terus membangun suatu teori Theos atau Tuhan dalam kacamata ilmu pengetahuan. Para kaum agnostisisme akan menuntut pembelaan kaum religi untuk dapat membuktikan keberadaan Tuhan secara ilmiah. Harus diakui, kemerosotan tingkat keagamaan khususnya di Eropa terjadi setelah adanya revolusi industri. Banyak dari antara kaum modern terus mempertanyakan keberadaan Tuhan, ditambah kondisi pada waktu itu manusia mengalami bencana perang, sosial, kelaparan, penyakit. Bagi kaum agnostik sendiri masih meragukan adanya keberadaan Tuhan. Bagi mereka, Tuhan dapat dipercaya keberadaan-Nya bila dibuktikan secara ilmiah. Abad 20-21 merupakan abad di mana manusia terus mengunggulkan ilmu pengetahuan atau sains, bagi mereka sains adalah satusatunya jalan menuju kebenaran serta bagian dari bentuk lahirnya sekularisme dalam post modern sampai era modernisme saat ini.

Kaum agnostik memiliki klaim, bahwa mereka akan berkata tidak percaya adanya dewa atau Tuhan serta juga tidak percaya bahwa tidak ada dewa atau Tuhan. Meskipun dalam pertimbangan mempertanyakan apakah ada Tuhan. Bagi kaum agnostik mereka akan mengatakan bahwa mereka adalah orang yang tidak bersalah, melihat fakta mereka tidak pernah mempertimbangkan dan mempertanyakan apakah ada dewa atau Tuhan. Bagi mereka untuk mempertimbangkan pertanyaan apakah ada Tuhan, seseorang harus memahami apa artinya sesuatu menjadi Tuhan? Itu adalah, seseorang yang perlu memiliki konsep mengenai Tuhan. Mereka mempertimbangkan konsep mereka seperti bayi yang baru berusia satu bulan, 
bahwa bayi satu bulan tidak memiliki konsep mengenai Tuhan dan bayi berusia satu bulan tidak bersalah. Kasus tidak bersalah dapat dilihat dari manusia yang telah menderita cedera otak traumatis yang parah, serta manusia dengan dimensia lanjut. ${ }^{1}$ Seorang ateis peraih Nobel fisikawan berpengaruh sepanjang masa Stephen Hawking, melihat keberadaan Tuhan dengan sudut pandang metafisika yang dipengaruhi oleh sains atau ilmu pengetahuan. Ada beberapa pertanyaan yang diajukan oleh Hawking di mana dia bertanya: Bagaimana kita dapat memahami realitas dunia terhadap diri kita? Hal apakah alam semesta berperilaku baik? Apa sifat suatu kenyataan? Apa penyebab semua ini berasal? Apakah Sang Pencipta dibutuhkan pada waktu alam diciptakan? Bahkan Hawking sendiri masih memiliki daftar pertanyaan seperti: Mengapa ada sesuatu daripada tidak ada? Mengapa kita ada? Mengapa seperangkat hukum khusus ini dan bukan hukum lain? Pertanyaanpertanyaan dari Hawking sebenarnya pertanyaan yang sudah ada sejak dulu, Hawking mencoba untuk melihat realitas dunia metafisika ini dengan kacamata ilmu pengetahuan. ${ }^{2}$

1 Graham Oppy, Atheism and Agnosticism (Cambridge University Press, 2018). 4

2 John C. Lennox, God And Stephen
Berbeda halnya dengan seorang ilmuwan terkenal yang bernama Albert Einstein Bagi Einstein, dia tidak mencoba membayangkan Tuhan yang berpribadi; itu cukup untuk mengagumi struktur dunia, sejauh memungkinkan indra kita yang tidak memadai untuk menghargainya. Dalam pernyataannya Einstein mengatakan agama tanpa pengetahuan mengalami kelumpuhan dan agama tanpa sains mengalami kebutaan. Bahkan dia mengatakan setiap manusia yang mencoba membaca agama yang dianut Einstein adalah suatu kebohongan, bahkan kebohongan yang tersistematis. Bagi dia perasaan religius sejati ketika melihat alam yang terstruktur begitu luar biasa dengan pemahaman manusia yang tidak sempurna. ${ }^{3}$

Tidak dapat dipungkiri, manusia akan mengandalkan rasionalitasnya untuk melampaui hal yang super being atau sesuatu hal yang sulit dilampaui. Filsafat dalam hal ini mencoba menjawab keraguan manusia untuk melihat alam semesta ini dengan teori causa prima. Tetapi berbeda halnya dengan sains atau ilmu pengetahuan yang mencoba melihat alam semesta ini tercipta dari proses gravitasi, lalu adanya teori ledakan besar yang dikenal big

Hawking Who Design Is It Anyway (Oxford OX2 8DR, England: Lion Hudson plc, 2011).15-16.

3 Richard Dawkins, The God Delusion (London: Bantam Press, 2006).22. 
bang dan teori-teori yang berkembang lainnya. Bahkan ilmu pengetahuan sendiri mencoba melihat penciptaan manusia dengan adanya teori evolusi. Hal ini sangat bertentangan dengan tradisi kitab suci khususnya Alkitab yang secara literal telah menuliskan peristiwa penciptaan dalam Kejadian pasal 1-2, ada Sang Inisiator yang disebut Allah berinisiatif menciptakan alam semesta sesuai rentetan hari. Penyangkalan dari para agnostik terhadap agama ketika mereka menghendaki adanya pembuktian yang dapat dipertanggungjawabkan secara ilmiah. Secara khusus mereka mencoba memahami akan natur Yesus yang adalah Tuhan adalah hal yang sangat tidak masuk akal, ditambah keberadaan-Nya yang sangat sulit untuk dijangkau. Maka untuk menjawab pertanyaan dari kaum agnostik akan eksistensinya, penulis akan menjawab dengan pendekatan apologetika, berapologi bukan hanya berbicara mempertahankan iman, melainkan memberikan pemahaman dalam bentuk presuposisi. Agnostik menjadi ancaman bagi kekristenan ketika mereka mencoba untuk meragukan bahkan apatis akan iman percaya terhadap Yesus Kristus. Tidak sedikitnya orangorang percaya menjadi agnostik disebabkan mereka mempercayai hal yang tidak dapat dibuktikan seiring dengan

\footnotetext{
${ }^{4}$ John W. Robbins, Cornelius Van Til
}

perkembangan zaman dan pola pikir.

Van Til mengatakan pendekatan presuposisi untuk menjawab akan keberadaan Tuhan dan kebenaran Alkitab harus diasumsikan atau diandaikan. Artinya untuk menjawab akan tuduhan para kaum agnostik Van Til memberikan cara dengan pendekatan asumsi atau diandaikan. $^{4}$ Setiawan mengatakan apologetika presuposisi sering kali dipakai oleh kelompok reformed dan digunakan sebagai alat melakukan apologetika guna mengandaikan suatu kebenaran Firman Tuhan. Setiawan mengatakan bahwa:

Kegiatan atau diskusi ini membuktikan seseorang yang merupakan orang percaya kepada Tuhan, pasti akan memegang wahyu-Nya sebagai pegangan otoritas kebenaran yang tertinggi meliputi aspek seluruh kehidupannya. Jika tidak demikian hal itu merupakan kesalahan atau dosa. Perihal demikian: teori ini menegaskan akan argumen apologetika tidak dapat netral serta memilih otoritas Allah dan firmanNya. Setiap orang percaya menghendaki sikap memuliakan Tuhan tentu saja ia seharusnya menempatkan Tuhan dan firman-

The Man and the Myth (The Trinity Foundation, 1986)...13. 
Nya melebihi segala-galanya. ${ }^{5}$

Penelitian serupa ditulis oleh Subeno yang membahas apologetika model presuposisi Van Til dalam menghadapi Gerakan Zaman Baru. ${ }^{6}$ Sedangkan artikel Setiawan juga memakai model presuposisi menghadapi pluralisme agama khususnya di Indonesia. ${ }^{7}$ Oleh sebab itu, penulis hendak menyajikan apologetika model presuposisi Van Til terhadap pemikiran agnostisisme.

Munculnya kelompok agnostik di masyarakat Indonesia merupakan fenomena sosial yang menarik perhatian penulis untuk dikaji dari sudut pandang apologetika iman Kristen. Orang Kristen perlu memiliki pemahaman yang tepat tentang apologetika presuposisi sehingga dapat menjawab tuduhan kaum agnostik mengenai eksistensi Tuhan.

Argumen penulis adalah bahwa berapologi model presuposisi yang ditawarkan Van Till tersebut mampu mempertanggungjawabkan keyakinan

\footnotetext{
${ }^{5}$ Andry Setiawan, “Apologetika Prasuposisional Triperspektivalisme John M. Frame Dan Aplikasinya Terhadap Pemikiran Kristen Pluralis Tentang Pluralisme Agama Di Indonesia," Veritas Vol.17, no. No.1 (2018): 6180 .

${ }^{6}$ Sutjipto Subeno, "Signifikansi Apologetika Trinitarian Cornelius Van Til Dalam Menghadapi Gerakan Zaman Baru," Verbum Christi: Jurnal Teologi Reformed Injili 1, no. 1 (September 6, 2017): 126-140, http://verbum.sttrii.ac.id/index.php/VC/article/vie $\mathrm{w} / 16$.

${ }^{7}$ Setiawan, "Apologetika
}

iman Kristen akan eksistensi Tuhan secara rasional sehingga dapat menjembatani agnostik mengenal Kristus sebagai puncak penyataan diri Allah kepada umat manusia.

Dikatakan Subeno, apologinya Van Til semua pengandaian diawali dengan Tuhan. ${ }^{8}$ Iman bagi Van Til sebagai pengandaian utama, yaitu membawa orang kepada Tuhan. Diakui Subeno gagasan presuposisi Van Til berakhir pada penginjilan. ${ }^{9}$ Penulis setuju bahwa kegiatan apologetika harus mencapai puncaknya pada penginjilan. Tujuan utama dari berapologi bukan memenangkan perdebatan teologis melainkan adalah penyampaian Injil untuk membawa seseorang kepada keselamatan di dalam Kristus. ${ }^{10}$ Di dalam kegiatan apologetika ada penginjilan, dan begitu sebaliknya di dalam usaha penginjilan terdapat unsur apologetika. Sebab itu, usaha menghadapi agnostik bukan sekadar berapologi untuk memenangkan debat tapi

Prasuposisional Triperspektivalisme John M. Frame Dan Aplikasinya Terhadap Pemikiran Kristen Pluralis Tentang Pluralisme Agama Di Indonesia."

${ }^{8}$ Subeno, "Signifikansi Apologetika Trinitarian Cornelius Van Til Dalam Menghadapi Gerakan Zaman Baru."

${ }^{9}$ Ibid.

${ }^{10}$ Kalis Stevanus, Apologetika:

Benarkah Yesus Itu Tuhan? (Yogyakarta: Andi, 2016).6-7 
fokusnya adalah melakukan penginjilan agar hati mereka diterangi oleh kebenaran firman-Nya sehingga dapat berbalik kepada Tuhan, sang Kebenaran itu sendiri. Dengan demikian, tiada gunanya menang debat teologis tapi gagal membawa orang kepada Tuhan.

\section{METODE PENELITIAN}

Metode penelitian yang dipilih untuk menjawab masalah dalam penelitian ini, maka penulis memilih menggunakan pendekatan kualitatif deskriptif dengan pendekatan studi kepustakaan. Metode kualitatif menitikberatkan pada temuan mengenai fenomena, kejadian maupun aktivitas sosial baik pribadi maupun kelompok dan disajikan secara deskriptif tanpa membuktikan sebuah teori. ${ }^{11}$ Sedangkan studi kepustakaan, penulis mengumpulkan berbagai sumber baik buku maupun artikel ilmiah yang berkaitan dengan topik pembahasan. Sumber-sumber tersebut dianalisis dan kemudian ditarik simpulan secara induktif.

\footnotetext{
${ }^{11}$ Kalis Stevanus, "Karya Roh Kudus Yang Karismatis Dalam Kisah Para Rasul," Shift Key : Jurnal Teologi dan Pelayanan 11, no. 2 (2021): 109-120. https://doi.org/10.37465/shiftkey.v11i2.196

${ }^{12}$ Kalis Stevanus, "Relasi Akal Budi Dan
}

\section{HASIL DAN PEMBAHASAN}

\section{Apologetika}

Apologetika merupakan kata yang berasal dari bahasa Yunani (apologia), yang memiliki arti pembelaan. Dalam praktiknya kata ini digunakan oleh Socrates sebagai bentuk pembelaan di hadapan pengadilan Athena. Kata ini juga digunakan oleh Alkitab sebanyak 8 kali dalam (Kis. 22:1; 25:16; 1Kor. 9:3; 2Kor. 7:11; Flp. 1:7, 16; 2Tim. 4:16; 1Ptr. 3:15), apologia juga memiliki sifat kata kerja menjadi apologeomai yang memiliki arti membela. Kata ini juga ditemui sebanyak 10 kali (Luk. 12:11; 21:14; Kis. 19:33; 24:10; 25:8; 26:1, 2, 24; Rm. 2:15; 2Kor. $12: 19) .{ }^{12}$

Stevanus turut menambahkan kata apologia dan apologeomai, dalam hal ini memiliki kaitan serta arti secara verbal, pertanggungjawaban, pembelaan diri atau mempertanggungjawabkan diri. Stevanus juga menambahkan teks Alkitab dari kata apologetika secara umum dapat dijumpai dalam surat 1 Petrus 3:15-16. Merujuk pada tugas setiap orang percaya untuk dapat memberikan jawaban imannya

Iman Dalam Apologetika Dan Pewartaan Injil," DUNAMIS: Jurnal Teologi dan Pendidikan Kristiani 6, no. 1 (October 20, 2021): 87-105, https://sttintheos.ac.id/e-

journal/index.php/dunamis/article/view/442. 
terhadap orang-orang di luar Kristus yang menuntutnya, inilah merupakan titik tolak serta sejarah munculnya apologetika yang kemudian dikenal dengan istilah locus classius (perkataan alkitabiah). ${ }^{13}$

\section{Pengertian Agnostisisme}

Dipaparkan Arizena, bila ditelusuri historisnya, agnostisisme dan ateisme dengan radikal menolak ide keberadaan Tuhan pada abad ke-18 dengan munculnya sains sehingga segala sesuatu menuntut pembuktian logis. Hal ini menjadikan orang menjauhi agama dan secara terang menyatakan penolakan terhadap Alkitab. ${ }^{14}$ Contoh kasus di Indonesia, adalah Yasim seorang yang menjauhi dan meninggalkan agama (menjadi orang yang tidak beragama) dan menyatakan dirinya sebagai seorang agnostik. Dilaporkan dalam penelitian Igbal Kamal terhadap Yasim, individu yang menyatakan dirinya sebagai seorang agnostik. Yasim dulunya seorang yang beragama hingga akhirnya terjadi krisis kepercayaan dan memilih meninggalkan agama atau menjadi tidak beragama. ${ }^{15}$

\footnotetext{
${ }^{13}$ Stevanus, Apologetika: Benarkah Yesus Itu Tuhan? .10

${ }^{14}$ Michela Sandra Arizena, "Kajian Terhadap Aliran Agnostisisme Dan Atheisme Di Indonesia" (STIKIP PGRI Sidoarjo, 2019), https://repository.stkippgrisidoarjo.ac.id/424/1/view.

${ }^{15}$ Iqbal Kamal, "Keraguan Agama: Studi
}

Agnostisisme tidak menyanggah Tuhan itu ada, tapi tidak mengakui keberadaan-Nya dapat dirasionalisasikan atau diterima logika. Agnostik nyata-nyata menyanggah bahwa pengetahuan ketuhanan dapat diklaim sebagai kebenaran. Bahkan mereka mengatakan kepercayaan agama itu hanya merupakan estetika psikologis manusia semata. Hal ini melahirkan paham pluralisme agama, di mana semua agama menjadi relatif yakni memiliki jalan keselamatannya masing-masing. Dengan demikian, secara eksplisit menolak iman Kristen yang menyatakan hanya di dalam Kristus saja manusia dapat diselamatkan. Sebab kaum Pluralis menolak keabsolutan Alkitab. ${ }^{16}$

Di dalam penelitian yang dilakukan Arizena di Indonesia sendiri sejak tahun 2008 telah ada kelompokkelompok yang menyatakan dirinya menolak gagasan atau konsepsi Allah. Mereka menyatakan diri baik melalui media digital hingga terbuka di khalayak umum. Sebab itu, keberadaan agnostik di Indonesia tidak boleh dipandang remeh oleh gereja.

\footnotetext{
Kasus Pada Individu Agnostik" (Universitas Islam Indonesia, 2021), https://dspace.uii.ac.id/handle/123456789/31552. ${ }^{16}$ Kalis Stevanus, "Relevansi Supremasi Kristus Bagi Pemberitaan Injil Di Indonesia," KAMASEAN: Jurnal Teologi Kristen 2, no. 1 (June 22, 2021): 32-46, https://kamasean.iakntoraja.ac.id/index.php/ojsdatakamasean/article/vie $\mathrm{w} / 51$.
} 
Secara umum agnostisisme memiliki arti harafiah tidak mengetahui, kata ini berasal dari bahasa Yunani pengetahuan dari kata gnostik dan a berarti tidak. Dapat disimpulkan secara sederhana pandangan ada atau tidak ada eksistensi Tuhan merupakan realitas yang tidak dapat diketahui. Beberapa pandangan menyatakan, agnostisisme berada di tengah sebagai kompromi teisme dan ateis. Beberapa orang akan menganggap bahwa kaum agnostik tidak memiliki jawaban, di samping itu agnostik berlawanan sisi dari para teis dan ateis dalam hal penetapan apakah Tuhan ada atau tidak.

\section{Sharma dalam Encyclopedia} International, mengemukakan pendapatnya tentang agnostisisme sebagai berikut: istilah agnostik dalam bahasa Yunani memiliki arti $a$ (tidak) dan ginosko (mengetahui) bila digabungkan menjadi tidak mengetahui. Istilah ini juga dipakai oleh Huxly guna memperlihatkan pandangan skeptis terhadap agama, serta bagaimana kegunaannya secara umum serta secara khusus merujuk pada sikap dan prinsip mereka yang percaya bahwa keberadaan Tuhan tidak dapat diketahui atau terbukti, dan siapa yang mendesak,

\footnotetext{
17 Edward Humphrey R.S. Sharma, "Agnosticm," Encyclopedia International (Columbia: Lexicon, 1978).225
}

oleh karena itu, penangguhan kepercayaan. ${ }^{17}$

Poidevin memberikan kriteria agnostik diantaranya: "Lemah" versus "kuat." Perbedaan pertama yang dibuat oleh Poidevin melihat antara dua kekuatan agnostisisme. Agnostisisme yang lemah, adalah posisi orang-orang yang sering mengenalnya; dan itu tidak lebih dari sebuah pengakuan bahwa seseorang tidak tahu apakah Tuhan itu ada. Agnostik kriteria lemah merujuk pada masalah pribadi: itu tidak mengomentari keyakinan orang lain. Sedangkan agnostik yang kuat lebih menarik, dikatakan bahwa kita tidak dapat melihat realitas apakah Tuhan itu ada atau tidak. Diperlukannya sesuatu tentang materi pembelajaran atau pengumpulan data yang membuat pengetahuan "tidak mungkin" dalam kasus ini. ${ }^{18}$

“Lokal” versus "global.” Agnostik bersifat lokal; diterapkan pada aspek tertentu dalam suatu materi pelajaran. Dalam iman Kristen khususnya, Poidevin mengatakan seorang Kristen yang masih percaya tetapi masih memiliki sifat agnostik; dapat dilihat dari berbagai pertanyaan yang disampaikan, seperti bagaimana Tuhan menjawab doa,

${ }^{18}$ Robin Le Poidevin, Agnosticism A Very Short Introduction (New York: Oxford University Press, 2010). 9 
mengapa Dia mengizinkan kejahatan, bagaimana ia menjadi inkarnasi dalam Kristus atau bahkan apa yang dilakukannya. Sedangkan agnostik global tidak terbatas pada urusan subjek tertentu. Pemikiran ini muncul dengan sejumlah besar argumen canggih yang dirancang untuk menggoyahkan kepercayaan pada kapasitas kita untuk mendapatkan pengetahuan tentang dunia. Mereka menarik perhatian tidak hanya pada ketidakmampuan indra, tetapi juga dengan sifat yang paling kontradiktif akal sehat kepercayaan, merusak alasan itu sendiri. ${ }^{19}$ Pembuktian dari hipotesis dapat dilihat dari setiap hipotesis, jika kita berpikir kita tidak dapat berada dalam posisi untuk menentukan apakah hipotesis itu benar atau tidak maka kita harus membuktikannya. ${ }^{20}$

Perbedaan Dawkins. Bagi dawkins, pertanyaan tentang keberadaan Tuhan adalah pertanyaan ilmiah hipotesis, dan agnostisisme apa pun tentangnya akan ada di TAP kategori (pertanyaan yang benar-benar ilmiah menjadi pertanyaan yang dapat kita memiliki jawaban prinsip). Tapi, menurutnya, mengingat apa yang sekarang diketahui tentang asal usul ras manusia dan asal usul kepercayaan agama, agnostisisme tidak lagi dibenarkan. Haruskah setuju?. ${ }^{21}$

Lahirnya pemikiran agnostisisme memunculkan gagasan baru bagi dunia skeptis. Salah satunya adalah David Hume, dengan teorinya Hume. Hume dalam penyelidikannya yang terkenal tentang manusia pemahaman dikatakan:

"Jika kita mengambil takaran apa pun; metafisika ketuhanan atau sekolah, misalnya; mari kita bertanya, apakah itu mengandung alasan abstrak tentang kuantitas atau angka? Tidak. Melakukannya mengandung alasan eksperimental tentang fakta dan keberadaan? Tidak. Berkomitmen kemudian ke nyala api: karena itu tidak dapat berisi apa pun selain tipu muslihat dan ilusi." Yaitu, pernyataan apa pun yang tidak murni hubungan ide (definitif atau matematis), di satu sisi, atau masalah fakta (empiris), di sisi lain, tidak ada artinya. Tentu saja, semua pernyataan tentang Tuhan berada di luar kategori ini, dan karenanya pengetahuan tentang Tuhan menjadi tidak mungkin. ${ }^{22}$ Sedangkan Kant, dia mewarisi

\footnotetext{
${ }^{19}$ Ibid. 13.

${ }^{20}$ Ibid. 15
}

${ }^{21}$ Ibid. 17.
22 Norman L. Geiser, Christian Apologetics (Michigan: Baker Academia, 2013). 3. 
tradisi pemikiran rasional Leibniz. Bagi Kant, bahwa ada dimensi rasional, apriori pada pengetahuan yaitu, bahwa bentuk dari semua pengetahuan tidak tergantung pada pengalaman. "Barang" pengetahuan disediakan oleh indra, tetapi struktur pengetahuan akhirnya dicapai dalam pikiran. Ini merupakan sintesis kreatif memecahkan masalah rasionalisme dan empirisme. Kant juga menegaskan, kita tahu fenomenanya tapi tidak tahu noumenanya. Ada jurang besar yang tak dapat dilewati antara dunia nyata dan pengetahuan kita tentangnya; kami harus tetap agnostik tentang kenyataan.

Ayer mengatakan semua pembicaraan mengenai Tuhan, adalah omong kosong atau kosong sama sekali. Pemikiran Ayer berkembang dari positivisme logis, bagi dia Tuhan tidak dapat diketahui dan tidak dapat diungkapkan. Bahkan tidak ada artinya untuk menggunakan istilah Tuhan. Untuk Ayer, kata Tuhan, atau transenden apa pun setara, tidak akan ada artinya. Oleh sebab itu, sangat sulit menjadi seorang agnostik. Istilah Tuhan juga bukan analitik atau sintesis; yaitu, tidak ditawarkan oleh para teis sebagai definisi kosong dan tanpa isi tidak sesuai dengan apa pun dalam kenyataan atau diisi dengan konten

23 Ibid. 5-6.

24 “CCornelius Van Til (1895-1987),” New empiris, karena “ Tuhan” diduga sebagai mahkluk empiris. Oleh karena itu, berbicara tentang Tuhan secara harfiah adalah omong kosong. ${ }^{23}$

\section{Apologetika Corneliuus Van Til Prasuposisional Triperspektivalisme Terhadap Agnostik}

Van Til merupakan tokoh yang sukses dalam perannya di dunia Apologetika Teologi, kontribusinya dalam ilmu filsafat agama, teologi, apologetika mengantarkan dia mendapatkan dua gelar kehormatan sebagai profesor di bidang apologetika di Princenton. Van Til beserta kedua rekannya di Seminari Teologi Princenton akhirnya memutuskan mendirikan Westminster Theological Seminary, sebuah seminari yang beraliran konservatif di pinggiran kota Philadelphia. Namanya selalu diingat sebagai spesialis apologetika, sebagai tokoh yang mengembangkan teori presuposisi. ${ }^{24}$ Van Til mengatakan manusia modern, yang dibesarkan dengan perbedaan-perbedaan fenomenalfenomenal Immanuel Kant akan segera menegaskan bahwa tidak ada artinya berbicara tentang Tuhan seperti itu. Tuhan itu, katanya, berada di luar pengalaman manusia. Dia tidak dapat diketahui. Tidak

Netherland Institute.Org. 
ada prediksi apa pun yang dapat dibuat tentang dia dalam istilah yang dapat dipahami pikiran manusia. ${ }^{25}$

Pengakuan Van Til di atas, menjadi problem terbesar ketika orang Kristen hendak berdiskusi atau berapologi mengenai iman mereka dapat dilihat, bagaimana kegagalan dari setiap orang Kristen yang mencoba untuk mempertahankan iman mereka disebabkan mereka tidak memiliki metode atau cara berapologi yang tersistematis. Sedangkan orang Kristen ketika berapologi mereka bukan hanya mempertahankan argumen iman mereka, tetapi mereka turut andil memberikan suatu pemahaman iman secara teologis yang mendasar.

Bahsen mengatakan apologetika presuposisi sebagai satu-satunya metode yang setia dan sehat untuk memperjuangkan harapan Kristen dan pesan alkitabiah. Bersandar pada otoritas Allah yang hidup daripada otoritas penalaran manusia yang independen, pembela harus mengandaikan kebenaran Alkitab dan mengepung semua anggapan

${ }^{25}$ Cornelius Van Til, An Introduction To Systematic Theology: Prolegomena and the Doctrines of Revelation, Scripture, and God, ed. William Edgar, Second Edi. (New Jersey: P\&R Publishing, 2007). 225.

26 Greg L. Bahnsein, Presuppositional Apologetics Stated and Defended, ed. Joel McDurmon (Texas: Covenant Media Press, 2008). murtad. ${ }^{26}$ Menurut Van Til sebagaimana dikatakan Peter Lillback, bahwa karena Tuhan berbicara dalam firman-Nya, adalah titik awal epistemologi yang paling akhir, tidak ada cara untuk memperdebatkan iman atas dasar sesuatu selain iman itu sendiri. Otoritas Tuhan adalah yang tertinggi dan dengan demikian membuktikan diri. Memperdebatkan iman pada otoritas lain mana pun berarti menganggap ada otoritas yang lebih tinggi daripada Tuhan sendiri. Oleh karena itu, Van Til menyarankan para apologis Kristen harus berdiri di atas dasar firman Tuhan yang otoritatif dan mampu menunjukkan kebodohan agnostik. ${ }^{27}$ Ditambahkan Setiawan bahwa berapologi model presuposisi yang digagas Van Til yang di kemudian hari dipopulerkan oleh para teolog reforms seperti Frame. Model apologetika presuposisi merupakan tindakan mempresuposisikan kebenaran Alkitab. Hal ini hendak membuktikan kepada kita bahwa seseorang harus terlebih dahulu memercayai eksistensi Tuhan. Bila ia memercayai eksistensi Tuhan tentu saja

371.

${ }^{27}$ Peter Lillback, "The Relationship Between Faith And Reason In Johannine Theology: A Biblical Affirmation of Presuppositional Apologetics," Verbum Christi: Jurnal Teologi Reformed Injili 1, no. 2 (September 6, 2017): 78-133, http://verbum.sttrii.ac.id/index.php/VC/article/vie $\mathrm{w} / 4$. 
akan menjadikan Alkitab sebagai standar kebenaran. ${ }^{28}$ Dengan kata lain, dalam praktik apologetika tidak ada posisi netral, dan harus memilih apa yang diungkapkan Alkitab sebagai kebenaran. Lagi, dikemukakan Stevanus bahwa permasalahan kunci dalam apologetika adalah kebenaran tentang eksistensi Tuhan. Perdebatan di antara orang Kristen dan orang agnostik pada dasarnya mengenai eksistensi Tuhan. Meskipun bantahan dan penolakan berkaitan dengan eksistensi Tuhan diajukan dalam pelbagai bentuk, sejatinya akar pertanyaan agnostik adalah: mengapa harus memercayai Tuhan itu ada? Bagaimana seseorang dapat mengetahui dan yakin dengan pasti Tuhan ada? Alkitab bukan mengandaikan Allah ada, tapi menyatakannya seperti tertulis di dalam Ibrani 11:6. ${ }^{29}$ Alkitab menyebut orang yang menyangkal eksistensi adanya Tuhan itu orang bebal, sebab orang bebal berkata dalam hatinya: tidak ada Allah (Mzm.14:1). Mereka juga disebut orang fasik, sebab orang fasik mengatakan: tidak ada Allah (Mzm.10:4).

Mengutip perkataan Bahsen bahwa metode presuposisi sangat

${ }^{28}$ Andry Setiawan, "Apologetika Prasuposisional Triperspektivalisme John M. Frame Dan Aplikasinya Terhadap Pemikiran Kristen Pluralis Tentang Pluralisme Agama Di Indonesia," Veritas: Jurnal Teologi dan Pelayanan 17, no. 1 (July 10, 2018): 61-80, https://ojs.seabs.ac.id/index.php/Veritas/article/vi ew/306. konsisten dan sangat jelas sudut pandang Alkitab sendiri, memiliki kesatuan atas seluruh bidang pengetahuan. Tuhan telah berbicara lewat proposisi linguistik, kebenaran tentang diri-Nya serta kebenaran mengenai manusia, rangkaian sejarah dan alam semesta. Kesatuan ini ada karena Tuhan. ${ }^{30}$ Van Til dalam tulisannya mengatakan apologetika merupakan pembenaran filosofi kehidupan iman Kristen terhadap beberapa bentuk filosofi kehidupan iman Kristen terhadap beberapa bentuk filosofi kehidupan di luar Kristen.

Sering kali apologetika dikatakan memiliki hubungan dengan teisme, sedangkan bukti berkaitan dengan kekristenan. Oleh karena itu, apologetika berhubungan dengan ilmu filsafat, berbeda hal dengan bukti yang berkaitan dengan fakta. ${ }^{31}$ Frame turut mengutip teori apologetika presuposisi yang ditawarkan oleh Van Til sangat baik dalam menjelaskan pengetahuan tentang Tuhan yang dimiliki oleh orang yang tidak percaya. Bagi Frame ada hal-hal yang dapat disetujui, semisal langit berwarna biru, $2+2=4$, hal ini disetujui karena

\footnotetext{
${ }^{29}$ Stevanus, Apologetika: Benarkah Yesus Itu Tuhan?72-73

30 Greg L. Bahnsein, Presuppositional Apologetics Stated and Defended.324.

31 Cornelius Van Til, Christian Apologetics, ed. William Edgar, Logos., n.d.6
} 
adanya bidang kesepakatan dan saling bekerja sama. Hal ini sangat berbeda bila berdebat dengan cara "mari kita asumsikan bahwa Alkitab bisa salah, dan mari kita menilai kebenarannya berdasarkan otoritas yang lebih tinggi dari indra dan logika kita." ${ }^{32}$ Artinya diperlukan suatu pendekatan presuposisi yang dapat menjawab akan perdebatan dengan agnostik.

Van Til menggunakan istilah praanggapan untuk menunjukan peran yang seharusnya dilakukan oleh wahyu Ilahi bermain dalam pikiran manusia. Ada beberapa contoh dalam tulisan penyampaian Van Til ketika ia menggunakan istilah praanggapan berbeda, misalnya; ia mendesak apologis untuk menunjukan orang non-Kristen dalam hal ini agnostik yang bahkan dalam penyangkalan virtualnya tentang Tuhan, dia masih benar-benar mengandaikan Tuhan. Sangat jelas, ketika orang yang tidak percaya mengandaikan Tuhan dalam pengertian ini, orang tersebut tidak mengakui Tuhan sebagai komitmen terakhir. Maksud dari Van Til di sini ialah dalam mengasumsikan kejelasan dunia, kafir secara implisit mengakui keberadaan

32 John M. Frame, ed., Cornelius Van Til : An Analysis of His Thought (Phillipsburg, New Jersey: Presbyterian and Reformed Publishing Company, 1995).3

33 John M. Frame, Cornelius Van Til
Tuhan yang secara eksplisit dia tolak. Bagi orang yang tidak percaya untuk mengandaikan Tuhan dalam konteks ini adalah baginya untuk berpikir, berkata, atau bertindak, bertentangan dengan kecenderungannya sendiri, yang menunjukkan pada beberapa tingkat kemampuannya kesadaran pengakuan akan realitas dan signifikansi Tuhan. ${ }^{33}$

Penegasan tentang pengetahuan tentang Tuhan secara alami dan inheren komprehensif tentang keberadaannya sendiri dan sebagai semua makhluk ciptaan berdasarkan kemahakuasaan-Nya di atasnya yang dituntut oleh manusia modern sebagai rasional. Dia yang berdasarkan Kitab Suci berani menegaskan kemahakuasaan dan oleh karena itu kemahatahuan Tuhan tanpa kualifikasi apa pun, pasti akan menghadapi tuduhan sebagai determinis dan rasionalis. ${ }^{34}$ Bagi Van Til, berdebat dengan cara praanggapan berarti menunjukkan apa saja prinsip-prinsip epistemologi dan metafisika yang mendasari dan mengendalikan metode seseorang.

Merujuk pada dasar dari semua doktrin Kristen adalah doktrin tentang

Analysis of His Thought (New Jersey: P\&R Publishing, 1995). 109.

${ }^{34}$ Cornelius Van Til, An Introduction To Systematic Theology: Prolegomena and the Doctrines of Revelation, Scripture, and God. 281. 
Tuhan yang berdiri sendiri, atau jika kita mau, doktrin Trinitas Ontologis. Metode penalaran dengan praanggapan dapat dikatakan tidak langsung daripada langsung, masalah di tengah orang percaya dan tidak percaya dalam teisme Kristen. Hal ini tidak dapat diselesaikan dengan banding langsung ke "fakta" atau "hukum" yang sifat dan signifikansinya telah disepakati oleh kedua belah pihak untuk diperdebatkan. Pertanyaannya lebih merujuk pada apa titik referensi akhir yang diperlukan untuk membuat "fakta" dan "hukum" dapat dipahami. Contoh halnya diskusi tentang "fakta".

Pembela Kristen harus memosisikan dirinya pada posisi lawannya, dengan mengasumsikan kebenaran metodenya hanya untuk kepentingan argumen, untuk menunjukkan kepadanya bahwa pada posisi seperti itu, "fakta" bukanlah keadaan nyata serta "hukum" bukanlah hukum. Pembela Kristen juga harus meminta orang non-Kristen untuk menempatkan dirinya pada posisi Kristen demi argumen agar dia dapat ditunjukkan bahwa hanya atas dasar seperti itulah "fakta" dan "hukum" tampak dapat dipahami. Oleh karena itu, mengakui praanggapan sendiri dan menunjukkan praanggapan orang lain berarti mempertahankan semua penalaran, dalam sifat kasusnya, penalaran melingkar. ${ }^{35}$

Secara dasar kaum agnostik lebih menekankan pada prinsip humanity. Urusan Tuhan bagi agnostik tidak terlalu dipikirkan secara iman, di sini penulis meyakinkan bahwa Tuhan bukan hanya bersifat transendental tetapi eksistensinya dapat dijumpai dengan pendekatan iman. Bukti bahwa keberadaan Tuhan dilihat dari keberadaannya diperlukan untuk keseragaman alam dan untuk koherensi semua hal di dunia.

Van Til memberikan contoh: kita tidak dapat membuktikan adanya balokbalok di bawah lantai jika dengan pembuktian yang kita maksudkan bahwa balok-balok itu harus dapat dipastikan dengan cara kita dapat melihat kursi dan meja pada ruangan tersebut. Tetapi gagasan lantai sebagai penopang meja dan kursi membutuhkan gagasan balok yang ada di bawahnya, dengan demikian; ada bukti yang benar-benar pasti tentang keberadaan Tuhan dan keberadaan teisme Kristen. Bahkan kaum agnostik mengandaikan kebenarannya sementara mereka secara verbal menolaknya. Mereka pada dasarnya memerlukan pengandaian kebenaran teisme Kristen 
untuk menjelaskan pencapaian mereka sendiri. ${ }^{36}$ Setiawan di sini mengatakan dalam Apologetika Konstruktif dalam perspektif Eksistensial, bahwa seorang apologis dapat membuktikan, menunjukkan kebenaran Kristen yang masuk akal bukan berdasarkan pada kemampuannya sendiri. Melainkan semua yang dikerjakan oleh Alkitab merupakan komitmen tertinggi bagi dirinya, hal ini dapat dilihat dari sikap rendah hati serta memegang prinsip tersebut secara konsisten, dan penuh ketaatan dalam kehidupannya. Implikasinya bahwa apologis dapat menafsirkan Alkitab dengan benar dan tepat, selain dari pada itu apologis dapat memberikan penjelasan proses keimanan di dalam Yesus Kristus dalam hal ini merujuk pada kaum agnostik dengan lemah lembut. ${ }^{37}$

Secara rasional kasus agnostik ini dapat dijawab, kecenderungan kaum agnostik secara rasio berkata bahwa realitas imanen sulit untuk dipahami akan keberadaannya, sesungguhnya mereka sedang mengaburkan akan prinsip imanen di sekitar mereka. Dalam presuposisi sebenarnya sudah dijelaskan dengan kita mengandaikan sesuatu untuk memahami

36 Ibid. 103.

37 Setiawan, "Apologetika Prasuposisional Triperspektivalisme John M. Frame Dan Aplikasinya Terhadap Pemikiran Kristen Pluralis Tentang Pluralisme Agama Di Indonesia." realitas di sekitar kita, kita akan menemukan sebab dan akibat yang terjadi. Pertanyaan yang sering muncul dari kalangan agnostik bahwa manusia tidak dapat mengetahui keberadaan Tuhan, bagi mereka Tuhan adalah pribadi yang irasional sehingga akal sangat terbatas untuk memahami bahkan mengerti keberadaan Sang Tuhan. Hal ini sangat mendapatkan perlawanan atau kritik tajam dalam golongan kekristenan, sebab kekristenan memahami bahwa Yesus yang adalah Tuhan menjadi manusia membuktikan bahwa realitas-Nya yang jauh dapat dijumpai dalam pribadi yang hadir dan menjadi manusia.

Stevanus menyatakan di dalam Injil, Yesus sendiri dengan terus terang mengatakan klaim-Nya bahwa melihat Dia berarti melihat Allah. ${ }^{38}$ Hal ini membuktikan bahwa Allah itu ada. Ia telah menjelma menjadi manusia di dalam diri Yesus Kristus. Identitas Yesus sekaligus menunjukkan keilahian-Nya. Artinya Allah dengan kemahakuasaanNya dapat menembus sekat antara rasional dan irasional. Yesus yang lahir dalam periode Masehi dan didukung oleh penemuan-penemuan baik itu secara

\footnotetext{
${ }^{38}$ Kalis Stevanus, "Bukti Keilahian Yesus Menurut Injil," Jurnal Teruna Bhakti 2, no. 2 (2020): 82-96, http://stakterunabhakti.ac.id/ejournal/index.php/teruna/article/view/49.
} 
literatur, kitab suci, bahkan arkeologi, hal ini mendukung akan eksistensi-Nya yang pernah ada di dunia. Bahkan Yesus itu sendiri dapat dijumpai dalam pengalamanpengalaman spiritual. Di sinilah dalam menjawab tantangan iman terhadap agnostik sebaiknya mereka digiring pada praanggapan, bagaimana semesta ini dapat ada bila tidak ada yang mengadakan-Nya.

Hal di luar nalar manusia bila sesuatu terjadi tanpa sebab bahkan pemicunya, alam semesta yang indah begitu beraturan bila tidak ada yang menciptakan maka secara akal tidak terjadi. Van Til memberikan contoh bagaimana kita bisa melihat bahwa meja terletak di atas balok-balok lantai, artinya meja tersebut tidak dapat berdiri sendiri tanpa ada penyangga yang memperlihatkan bahwa ada di atas balokbalok lantai. Hal yang sama dapat dilihat ketika alam tidak ada yang mengatur sedemikan begitu baik bila tidak ada Sang Pengatur yaitu Tuhan. Singkatnya, apakah agnostik, apakah rasionalis atau induktivis, menganggap hukum alam sebagai sesuatu yang mutlak dan ada dengan sendirinya. Para deis sebelum Locke, secara umum, adalah induktivis, tetapi keduanya sama-sama bersikeras

${ }^{39}$ Cornelius Van Til, Christian Theistic Evidences, ed. K. Scott Oliphint, Second Edi. (New Jersey: P\&R Publishing, 2018). 264.

${ }^{40}$ Greg L. Bahnsein, Presuppositional pada swasembada hukum alam semesta. Jika Tuhan memiliki tujuan apa pun dengan alam semesta, itu semua diungkapkan dalam tindakan penciptaan yang asli. Meski begitu para kaum rasionalis tidak memiliki pandangan alkitabiah tentang penciptaan, demikian Tuhan. ${ }^{39}$ Ketergantungan rasionalistik pada pikiran dan cara kita sendiri menuju wahyu Tuhan, kita belajar untuk bertanyatanya pada dunia; dalam melakukannya kita bertanya-tanya pada Tuhan yang tidak dapat dipahami yang membuat dan mengarahkannya. Dalam menegaskan bahwa Tuhan tidak dapat dipahami, kita tunduk pada pemikiran-Nya dan belajar bahwa makhluk tidak boleh mengingini hak prerogatif dan atribut epistemologisNya. ${ }^{40}$

Van Till juga menandaskan manusia harus bernalar secara analogi dari alam ke Tuhan alam. Oleh karena itu, manusia harus menggunakan argumen kosmologis secara analogi agar dapat memberikan simpulan bahwa Tuhan adalah pencipta alam semesta ini. Manusia juga harus menggunakan argumen ontologis secara analogi. ${ }^{41}$ Dari penguraian di atas apologetika presuposisi triperspektivalisme Van Till dapat Apologetics Stated and Defended. 137.

${ }^{41}$ John W. Robbins, Cornelius Van Til The Man and the Myth. 14. 
digunakan guna menjawab tantangan pemikiran kelompok agnostik. Hal ini dapat dibuktikan dengan model apologetika presuposisi triperspektivalisme Van Till yang tetap tunduk pada otoritas Alkitab, sembari menjelaskan bahwa kekristenan itu masuk akal sehingga dapat mempertahankan iman Kristen, baik itu secara kontekstual serta pertanyaan yang diajukan oleh kelompok agnostik terhadap kekristenan.

\section{KESIMPULAN}

Pembahasan di atas penulis menarik kesimpulan, bahwa studi apologetika presuposisi terhadap agnostik dapat dilihat dari studi apologetika terhadap kaum ilmiah. Ada bukti yang benar-benar pasti mengenai keberadaan Tuhan dan keberadaan teisme Kristen baik di dalam Alkitab maupun di luar Alkitab. Allah itu ada dan keberadaan-Nya dekat (imanen) dengan ciptaan-Nya serta bekerja aktif dalam keberlangsungannya. Setiap ciptaan-Nya mengalami kehadiran dan campur tangan-Nya. Hal ini menunjukkan bukti kuat dan rasional adanya gagasan tentang Tuhan secara universal di dalam pikiran manusia. Dengan kata lain, secara kognitif sejatinya agnostik yang menyanggah keberadaan Tuhan kontradiksi dengan faktual yang ada. Tuhan telah menyatakan diri-Nya melalui ciptaan-Nya. Manusialah yang secara sengaja dan terus menerus menolak pengetahuan dan menindas kesadaran adanya Tuhan secara teoretis maupun praktis. Melalui model apologetika presuposisi triperspetivalisme menunjukkan sebuah fondasi logis (dasar rasional) bagi keyakinan iman Kristen sebagai keyakinan yang benar. Tujuan akhir dari berapologi presuposisi ini tidak lain adalah membawa orang kepada Tuhan di dalam Kristus.

\section{DAFTAR PUSTAKA}

Arizena, Michela Sandra. "Kajian Terhadap Aliran Agnostisisme Dan Atheisme Di Indonesia." STIKIP PGRI $\quad 2019$. https://repository.stkippgrisidoarjo.ac.id/424/1/view.

Cornelius Van Til. An Introduction To Systematic Theology: Prolegomena and the Doctrines of Revelation, Scripture, and God. Edited by William Edgar. Second Edi. New Jersey: P\&R Publishing, 2007. . Christian Apologetics. Edited by William Edgar. Logos., n.d. . Christian Theistic Evidences. Edited by K. Scott Oliphint. Second Edi. New Jersey: P\&R Publishing, 2018.

Dawkins. Richard The God Delusion. London: Bantam Press, 2006.

Frame, John M., ed. Cornelius Van Til: An Analysis of His Thought. Phillipsburg, New Jersey: Presbyterian and Reformed Publishing Company, 1995.

Graham Oppy. Atheism and Agnosticism. 
Cambridge University Press, 2018.

Geiser. Norman L. Christian Apologetics. Michigan: Baker Academia, 2013.

Greg L. Bahnsein. Presuppositional Apologetics Stated and Defended. Edited by Joel McDurmon. Texas: Covenant Media Press, 2008.

John C. Lennox. God And Stephen Hawking Who Design Is It Anyway. Oxford OX2 8DR, England: Lion Hudson plc, 2011.

John M. Frame. Cornelius Van Til Analysis of His Thought. New Jersey: P\&R Publishing, 1995.

John W. Robbins. Cornelius Van Til The Man and the Myth. The Trinity Foundation, 1986.

Kamal, Iqbal. "Keraguan Agama: Studi Kasus Pada Individu Agnostik." Universitas Islam Indonesia, 2021. https://dspace.uii.ac.id/handle/12345 6789/31552.

Lennox, John C. God And Stephen Hawking Who Design Is It Anyway. Oxford OX2 8DR, England: Lion Hudson plc, 2011.

Lillback, Peter. "The Relationship Between Faith And Reason In Johannine Theology: A Biblical Affirmation Of Presuppositional Apologetics." Verbum Christi: Jurnal Teologi Reformed Injili 1, no. 2 (September 6, 2017): 78-133. http://verbum.sttrii.ac.id/index.php/ VC/article/view/4.

R.S. Sharma, Edward Humphrey. "Agnosticism." Encyclopedia International. Columbia: Lexicon, 1978.

Robbins, John W. Cornelius Van Til The Man and the Myth. The Trinity Foundation, 1986.

Robin Le Poidevin. Agnosticism A Very
Short Introduction. New York:

Oxford University Press, 2010.

Setiawan, Andry. "Apologetika

Prasuposisional Triperspektivalisme John M. Frame Dan Aplikasinya Terhadap Pemikiran Kristen Pluralis Tentang Pluralisme Agama Di Indonesia." Veritas Vol.17, no. No.1 (2018): 61-80.

Stevanus, Kalis. Apologetika: Benarkah Yesus Itu Tuhan? Yogyakarta: Andi, 2016.

. "Bukti Keilahian Yesus Menurut Injil." Jurnal Teruna Bhakti 2, no. 2 (2020): 82-96.

http://stakterunabhakti.ac.id/ejournal/index.php/teruna/article/vie $\mathrm{w} / 49$.

. "Karya Roh Kudus Yang Karismatis Dalam Kisah Para Rasul." Shift Key: Jurnal Teologi dan Pelayanan 11, no. 2 (2021): 109-120.

. "Relasi Akal Budi Dan Iman Dalam Apologetika Dan Pewartaan Injil." DUNAMIS: Jurnal Teologi dan Pendidikan Kristiani 6, no. 1 (October 20, 2021): 87-105. https://sttintheos.ac.id/ejournal/index.php/dunamis/article/vi ew/442.

\section{"Relevansi Supremasi Kristus} Bagi Pemberitaan Injil Di Indonesia." KAMASEAN: Jurnal Teologi Kristen 2, no. 1 (June 22, 2021): 32-46.

https://kamasean.iakntoraja.ac.id/index.php/ojsdatakamase an/article/view/51.

Subeno, Sutjipto. "Signifikansi Apologetika Trinitarian Cornelius Van Til Dalam Menghadapi Gerakan Zaman Baru." Verbum Christi: Jurnal Teologi Reformed Injili 1, no. 1 (September 6, 2017): 126-140. 
http://verbum.sttrii.ac.id/index.php/ VC/article/view/16.

"Cornelius Van Til (1895-1987)." New

Netherland Institute.Org. 
90 | SANCTUM DOMINE: Jurnal Teologi, vol. 11, no. 1 (2021) 